Research, part of a Special Feature on The Governance of Adaptation

\title{
The Adaptation Policy Paradox: the Implementation Deficit of Policies Framed as Climate Change Adaptation
}

\author{
$\underline{\text { Johann Dupuis }}^{l}$ and $\underline{\text { Peter Knoepfel }}^{1}$
}

\begin{abstract}
The implementation of adaptation policies suffers from barriers and limits; even though adaptation is now set on the political agendas of developed and developing countries, surprisingly few examples of concrete policy realizations are found in comparative assessments. We investigate how the framings of adaptation as a policy problem can relate to tractability issues in implementation. We distinguish three framings of adaptation: climate change adaptation (CCA), climate variability adaptation (CVA), and vulnerability-centered adaptation (VCA) that imply conflicting interpretations of the collective problem to be solved and the goals to be attained through policy solutions. Through the methodology of comparative case studies, we conduct an empirical analysis of three implementation processes in India and Switzerland, and examine how adaptation framings translate into formal policy design and concrete policy realizations. We find that, regardless of the adaptive capacity of the country where implementation takes place, the CCA framing meets more tractability issues than the VCA framing. Therefore, we discuss the paradox that the innovative and additional CCA types of policies, advocated by the United Nations Framework Convention on Climate Change (UNFCCC), are more likely to face a deficit in implementation according to our analysis.
\end{abstract}

Key Words: adaptation; adaptive capacity; barriers; climate change; framing; implementation; policy coordination; policy design; political sciences; public policy; tractability

\section{INTRODUCTION}

The need to develop public policies to adapt to the impacts of climate change has been emphasized since the beginning of the United Nations Framework Convention on Climate Change (UNFCCC) negotiations in the early 1990s (Oberthür and Ott 1999). However, a striking feature has been underlined by the recent assessment of public adaptation policies: whereas adaptation has appeared on the political agenda in many countries, implementation has rarely occurred (Biesbroek et al. 2010, Ford et al. 2011). Public adaptation policies have often consisted of enunciating general objectives, formulating guidelines, and funding climate impact research programs; however, concrete actions seem to lag behind (Keskitalo 2010). Consequently, public adaptation policies often appear to be little more than "empty shells," and it can be argued that current policy making is facing an "implementation deficit" (Bardach 1977, Pressman and Wildavsky 1984, Knoepfel et al. 2011) that is characterized by the gap between the more or less binding prescriptions concerning adaptation included in the UNFCCC (Articles $4 e$ and $4 f$ ) or the authoritative reports of the Commission of the European Communities (2007, 2009), and the lack of effective actions by state and sub state authorities.

The reasons underlying the public adaptation policy implementation deficit are not completely addressed by the literature to date. Up to the publication of the fourth report of the IPCC in 2007, the capacity of states to develop public adaptation policies has been described using the concept of "adaptive capacity," that is, "the whole of capabilities, resources and institutions of a country or region to implement effective adaptation measures" (Intergovernmental Panel on Climate Change 2007). The emphasis on adaptive capacity has led to a functional interpretation of the policy process in which the aptitude to formulate and implement policies has been essentially measured using macro indicators such as per capita GDP or literacy rates, that are strongly related to economic development levels (Smit et al. 2001), but which fail to account for the process-intensive and complex nature of policy making (Wellstead et al. 2013). Therefore, a predominant and longstanding view has been that industrialized countries, which have a relatively high adaptive capacity, would respond almost naturally to climate change impacts, whereas adaptation was seen as a challenge facing developing countries (Gagnon-Lebrun and Agrawala 2006, Wolf 2011).

More recently, scholars have started moving away from this functional interpretation of the policy process, and have engaged in the examination of the various barriers that limit adaptation policy (Adger et al. 2007). Several factors have been identified; notably, the uncertainty of available scientific knowledge which prevents decision making (Wilby and Dessai 2010); the fragility of ecosystems which renders null certain forms of policy intervention (Hulme 2005); the costbenefit ratio of adaptation measures which is not always favorable to public action (Economics of Climate Adaptation Working Group 2009); the lack of economic resources (Global Environmental Facility 2010); the weakness of state institutions that are unable to design and implement public 
adaptation policy (Yohe et al. 2006); and social limits that might prevent adaptation responses in certain contexts (Adger et al. 2009).

Although these studies have contributed to enlarging our current understanding of adaptation policy processes, we argue that some issues remain. First, the concept of adaptation policy is often used problematically in the adaptation literature (Dupuis and Biesbroek 2013). Previous studies of adaptation policy have often considered various types of adaptation, such as public, private, incidental, or purposeful, together (Tompkins et al. 2010)—despite the fact that these types of adaptation result from dissimilar decision processes that may not be subject to the same barriers. Second, the concept of barriers to adaptation is somewhat undertheorized and has been used phenomenologically to list existing hindrances to public adaptation policy, leaving aside the explanation of their origins or the causal mechanisms by which they operate (Biesbroek et al. 2013). It is surprising to note the extent to which knowledge, theories, and conceptual frameworks from sociology and the policy sciences have barely been considered by the research in explaining the political and institutional factors that might hinder the adaptation policy process (Dovers and Hezri 2010, Dupuis and Knoepfel 2011). Third, the implementation of public adaptation policy is still scarcely studied, although it is absolutely the stage where feasibility issues arise from the translation of abstract policy objectives into concrete public actions (Hjern and Hull 1982, Barrett 2004).

In studying governance processes, political scientists usually differentiate among three interrelated dimensions: (1) politics, or the structured power relations between political actors; (2) policy, or the substantial action of the state; and (3) the polity, as the system of rules and norms that shape actors' behavior (Treib et al. 2007). We focus on the policy dimension of the governance of adaptation, and examine the tractability of adaptation framings in implementation processes. Framing can be defined very broadly as the "point of view or perspective from which ill-defined problematic situations are given meaning by people and institutions" (Hisschemöller and Hoppe 1995). It is widely recognized that competing framings of adaptation have been conveyed by scholars and international institutions such as the Intergovernmental Panel on Climate Change (IPCC) and the UNFCCC (Brooks 2003), but how these framings are being translated into formal policy designs, and with what consequences for their implementation has been barely studied (see Eakin et al. 2009, Juhola et al. 2011). Our research will attempt to fill this gap.

\section{THEORIES}

Borrowing from the policy sciences, we define public policy as "a series of intentionally coherent decisions or activities taken or carried out by different public and sometimes private actors, [...] with a view to resolving in a targeted manner a problem that is politically defined as collective in nature" (Knoepfel et al. 2011:24).

This definition points out two necessary conditions that qualify what we consider to be "public adaptation policy." These are: (1) the production of deliberated decisions or (non)actions that involve public actors, at least to some degree (Nadel 1975); and (2) the intention to solve what is perceived as one or several collective problems (Howlett and Ramesh 1995). Public policy is characterized by the nature of the issues it deals with (Peters 2005). Therefore, and by definition, adaptation policy is "intentional" (Smithers and Smit 1997); that is, a so-called adaptation policy must include climate change impacts in its problem definition (see Moser and Ekstrom 2010 for a similar approach).

Public policy is often conceived of as a multi-stage and multilayered process; policies are designed in a programming phase prior to their implementation at various scales and levels of governance (Parsons 1995, Hill and Hupe 2003). Programming involves formalizing key aspects such as the collective problem to be solved, goals to be achieved, instruments that are intended for behavioral change, target groups that are allocated burdens and benefits, and an overarching rational that should coherently connect these elements (Ingram et al. 2007). On the other hand, implementation can be defined as "the set of processes after the programing phase that are aimed at the concrete realisation of the objectives of a public policy" (Knoepfel et al. 2011:196). Implementation hence corresponds to the stage of the policy process where policy outputs, in the form of actions, regulations, information, or goods and services, are directed at or delivered to the targets of the policy.

Public policies often fail to realize their stated intentions: implementation research has made clear that goals and objectives contained in law and policy documents often stay on paper because of the numerous obstacles that plague implementation processes (Hupe 2011). Implementation often produces merely symbolic effects (Hoppe et al. 1987), or even nondecisions (Bachrach and Baratz 1963) that are parts of the usual portfolio of actions of public authorities and that can be crowned with political success (Marsh and McConnell 2010). However, if we understand vulnerability to climate change impacts as the broad issue to be resolved through adaptation policy (Doria et al. 2009), then "implementation success" should be defined as the capacity to produce policy outputs that contribute substantially to reducing the vulnerability to climate change of actor groups, sectors, or geographical areas (Dupuis and Biesbroek 2013). Inversely, we define "implementation deficit" as the outputs of a policy failing to contribute more than symbolically to problem solving.

\section{Adaptation framings}

A very large number of factors can potentially influence implementation (Goggin 1986, O'Toole 2004). We focus on 
Table 1. Ideal types of adaptation framings.

\begin{tabular}{|c|c|c|c|c|}
\hline Framing & Problem & Goals & Solutions & Promoter \\
\hline $\begin{array}{l}\text { Climate change adaptation } \\
\text { (CCA) }\end{array}$ & $\begin{array}{l}\text { Anthropogenic climate } \\
\text { change exerts impacts that } \\
\text { are additional to, and exceed } \\
\text { the magnitude, intensity, or } \\
\text { frequency of, natural } \\
\text { variability }\end{array}$ & $\begin{array}{l}\text { Adapt to the specific impacts } \\
\text { of anthropogenic climate } \\
\text { change }\end{array}$ & $\begin{array}{l}\text { Transformational or } \\
\text { additional measures } \\
\text { Climate-model informed } \\
\text { realizations } \\
\text { Future risk-reduction } \\
\text { strategies }\end{array}$ & $\begin{array}{l}\text { First assessment report of the } \\
\text { IPCC (Pentland et al. } \\
\text { 1990:166); Article 4, } \\
\text { UNFCCC (United Nations } \\
\text { 1992) }\end{array}$ \\
\hline $\begin{array}{l}\text { Climate variability adaptation } \\
\text { (CVA) }\end{array}$ & $\begin{array}{l}\text { Climate variability, which is } \\
\text { basically a deviation from } \\
\text { climate norm, is problematic } \\
\text { for the present and future, } \\
\text { independent of its causes }\end{array}$ & Adapt to climate variability & $\begin{array}{l}\text { Risk-recovery strategies } \\
\text { Stationary risk-anticipation } \\
\text { strategies } \\
\text { Weather insurance }\end{array}$ & $\begin{array}{l}\text { Second and third assessment } \\
\text { reports of the IPCC } \\
\text { (Trenberth et al. 1995:56, } \\
\text { Smit et al. 2001:984) }\end{array}$ \\
\hline $\begin{array}{l}\text { Vulnerability-centred } \\
\text { adaptation (VCA) }\end{array}$ & $\begin{array}{l}\text { Vulnerability to climate } \\
\text { change is a symptom of a } \\
\text { more general vulnerability to } \\
\text { external stresses caused by a } \\
\text { range of endogenous and } \\
\text { societal factors }\end{array}$ & $\begin{array}{l}\text { Reduce the structural drivers } \\
\text { of vulnerability to climate } \\
\text { change impacts }\end{array}$ & $\begin{array}{l}\text { Poverty-reduction measures } \\
\text { Sustainable natural resource } \\
\text { management } \\
\text { Sustainable economic } \\
\text { development }\end{array}$ & $\begin{array}{l}\text { Fourth assessment report of } \\
\text { the IPCC (Adger et al. 2007) }\end{array}$ \\
\hline
\end{tabular}

problem framing, which corresponds to the process of idea formulation that "involves the selective use of knowledge and information about a problem and the causal relationships surrounding it, to give it meaning and render it manageable" (Ward et al.2004). Framings of collective problems are central to understanding the policy process, as they act as a flux of ideas that eventually diffuse in the design of formal policies (Miller 2000, Campbell 2002); problem framing contributes to the general orientation of policy design and the types of policy outputs that are likely to be delivered through implementation (Peters 2005). Here, we operationalize problem framing as a logically articulated discourse about a collective "problem" that is to be solved by reaching "goals" through "policy solutions."

The relationship between problem framing and implementation is a particularly interesting one in the context of adaptation, because competing framings of adaptation have been conveyed by international institutions and scholars (Brooks 2003, O'Brien et al. 2007, Füssel et al. 2012). This partially explains why adaptation has been called a "wicked problem par excellence" (Termeer et al. 2013). Three ideal types of adaptation framing can be distinguished (see Table 1). The first assessment report of the IPCC (Pentland et al. 1990:166) and the initial text of the UNFCCC (see Article 4) promoted a climate change-centered view of adaptation (CCA) that defines the impacts of anthropogenic climate change as the problem to be solved. Vulnerability is seen as resulting specifically from climate change stimuli that are considered as supplementary to, and out of the range of, natural variability. Resulting from this is the view that needed policy solutions are additional (Mceldowney 1997) to existing policies and are based on new, innovative, and generally highly technical measures that are able to deal with unprecedented risks in term of scale and intensity (Kates et al. 2012).

Starting from its second assessment report, the IPCC officially diverged from the view of the UNFCCC and renounced the distinction between anthropogenic climate change and natural variability (Trenberth et al. 1995:56). Here, the goal of adaptation is defined as "adapting to climate variability" (CVA), that is, significant variations from the climate norm that occur regardless of human influences. The unprecedented dimension of anthropogenic climate change is thus somewhat downplayed. It is suggested that adaptation policies should prioritize the reduction of present exposure through riskreduction policies, given that many societies do not adequately deal with present variability, and that uncertainty characterizes future climate predictions (Pielke 2005).

Finally, the IPCC fourth assessment report (Adger et al. 2007) adopts a "vulnerability-centered adaptation" (VCA) perspective; it defines the collective problem as not being caused solely by climate variability or change, but by a range of social, environmental, and economic factors that limit the present capacity to adapt to external stressors. From this perspective, the goal of adaptation policy is not limited to the mitigation of climate stimuli, but embraces a more holistic approach that: (1) emphasizes policy solutions that increase the welfare of vulnerable groups, (2) focuses on the good management of natural resources, or (3) contributes to sustainable development. 


\section{Tractability of adaptation framings}

Problem framings are not "tractable" to the same extent; tractability concerns the political, societal, and technical capacity of managing and taming a collective problem through proposed policy solutions (Hisschemöller and Hoppe 1995); a gap might form between the policy solutions that would be needed to contribute to problem solving according to certain framings, and the outputs that can be truly delivered through implementation.

We argue that, all things being equal, the characteristics of the climate change adaptation (CCA) framing make it more prone to tractability issues. First, from a macro-level perspective, implementing policies that are designed according to the CCA framing requires extensive knowledge about climate projections, along with technical competencies that are not available in every context. Therefore, McGray and al. (2007) have suggested that requirements in adaptive capacity create a continuum between adaptation policies; the VCA framing is deemed to be more feasible than the CCA framing because addressing the drivers of vulnerability does not imply such high prerequisites. Because adaptive capacity correlates to levels of economic development (Smit et al. 2001), McGray and al.'s argument suggests that the CCA framing would be more tractable in developed countries than in emerging or developing countries; this needs to be empirically verified.

Second, at the meso level, adaptation policy in general is very likely to be plagued by conflicts of "intra-policy coordination" (Knoepfel 1995, Lafferty and Hovden 2003): as a means of dealing with a complex problem that spans the goals of several policy sectors, adaptation will necessitate articulating competitive problems and goals in the same policy design. This is unlikely to go without provoking ambiguity and tradeoffs during implementation (Matland 1995). Furthermore, the CCA framing might be specifically concerned by the issue of "inter-policy coordination" (Knoepfel 1995, Varone et al. 2013): the implementation of adaptation policies does not take place in an institutional void, and the kind of innovative, largescale, or intense policy solutions that are implied by the CCA framing might conflict with the effects of other existing policies; notably, sustainability policies (Urwin and Jordan 2008, Eriksen et al. 2011).

Third, at the micro level, the network of actors involved in the implementation of regional or local adaptation policies might oppose the goals, values, or beliefs embedded in the CCA framing. Climate change impacts were first framed as a policy problem by international institutions in the early 1990s (Schipper 2006). Such highly distant political definition of collective problems can be fairly divorced from what local stakeholders perceive to be urgent and severe issues that should be given priority for resolution by public action (Rochefort and Cobb 1994). Indeed, the gap between how toplevel institutions frame a politically defined problem and the preferences of local stakeholders involved in implementation often explains why policies fail to achieve initial expectations (Lipsky 2010). Given that the CVA and VCA framings are based on problem definitions that have a wider scope which might be more salient locally, they are more likely to be supported by implementation actors.

\section{METHODS}

We seek to explore whether certain adaptation framings are less tractable and, if so, why. Furthermore, we want to verify if eventual patterns of causation between adaptation framings and tractability issues are specific to developing countries with weak adaptive capacity, or if they might also hold in more wealthy nations.

\section{Case selection}

We have based this research on the methodology of comparative case studies (Seawright and Gerring 2008). First, we selected a pair of highly similar regional-level policies within a developing country. As much as possible, chosen cases matched control variables; this allowed us to assess the impact of adaptation framings on implementation outcomes. Second, we verified whether the relationships observed were robust to situational variation in the context of implementation, by conducting the same analysis on a very different case that was chosen in an industrialized country with high adaptive capacity (Anckar 2008). Adaptive capacity was approximated using the human development index (Malik 2013), which, according to Füssel (2010), accurately represents the economic, social, and institutional coping capacity of a country.

Table 2 summarizes the main characteristics of the three cases selected, as well as their context. India was chosen to represent developing economies with low adaptive capacity. Two rural development policies in the semi-arid areas of Rajasthan and Maharashtra at the regional level are compared. The two policies deal with change in rainfall patterns and drought risks affecting poor farmers through instruments typical of sustainable resource management. Switzerland was chosen as a typical case representing most-developed liberal democracies with high adaptive capacity. We analyzed a single rural development policy that mixes economic and regulatory instruments, which addresses the consequences of temperature increases and resulting changes in snowline elevation for tourism companies operating in low-lying areas.

\section{Data analysis and collection}

Data analysis followed a 3-step procedure. First, we analyzed how adaptation framings are translated into formal policy designs. The initial design of each policy was studied using qualitative discourse analysis (Hajer and Versteeg 2005). We identified the problem and corresponding goal formulation in the relevant policy documents, which were provided directly by the implementing agencies. Problem and goal formulation 
Table 2. Comparative research design.

\begin{tabular}{|c|c|c|c|}
\hline \multirow[b]{2}{*}{ Case study } & \multicolumn{2}{|c|}{ India } & \multirow{2}{*}{$\begin{array}{c}\text { Switzerland } \\
\text { "Alpes Vaudoises" rural } \\
\text { development policy }\end{array}$} \\
\hline & $\begin{array}{l}\text { Vulnerability \& Assessment program } \\
\text { (V\&A) program }\end{array}$ & $\begin{array}{l}\text { WOTR climate change adaptation } \\
\text { program }\end{array}$ & \\
\hline \multicolumn{4}{|l|}{ Contextual variables } \\
\hline Country type & developing country & developing country & developed liberal democracy \\
\hline Adaptive capacity (HDI index) & $136 / 186$ & $136 / 186$ & $9 / 186$ \\
\hline \multicolumn{4}{|l|}{ Control variables } \\
\hline Location & Rajasthan & Maharashtra & Vaud (region of Aigle) \\
\hline Scale & regional & regional & regional \\
\hline Sector & rural development & rural development & rural development \\
\hline Geographical area & semi-arid agricultural area & semi-arid agricultural area & low-lying alpine resorts \\
\hline Targets & poor farmers in rain-fed areas & poor farmers in rain-fed areas & winter tourism companies \\
\hline Main instruments & sustainable resource management & sustainable resource management & $\begin{array}{c}\text { economic subsidies and regulatory } \\
\text { instruments }\end{array}$ \\
\hline Time period & $2005-2009$ & $2009-201 ?$ & $2003-201 ?$ \\
\hline Climate risks addressed & change in rainfall patterns, drought & change in rainfall patterns, drought & $\begin{array}{c}\text { temperature increase, snowline } \\
\text { elevation }\end{array}$ \\
\hline
\end{tabular}

were then classified as CCA, VCA, or CVA, according to their lexical proximity with these ideal types.

Second, we assessed the tractability of adaptation framings by identifying the policy outputs that were produced in relation to each problem and goal formulation, and by assessing their problem-solving contribution. Outputs were classified according to the classical threefold typology proposed by Bemelman-Videc and al. (1998) into (1) "information measures," which consists of preventing wrong, or stimulating right, conduct through the transfer of knowledge; (2) "economic means" which involve handing out or taking away material resources, whether cash or in-kind; and (3) "regulation," defined as the measures taken to influence people by means of formulated rules and directives. The problemsolving contribution of outputs produced was then assessed qualitatively by the authors using two criteria. The first criterion is the "density" of policy outputs (Holzinger et al. 2011), which concerns the capacity to produce public measures and is evaluated in terms of quantity of outputs, or in terms of the failure to implement foreseen actions. The second criterion is the "impacts" of policy outputs (Knoepfel et al. 2011); namely, the extents to which outputs are able to provoke a durable change in the behavior or situation concerning the policy targets. The necessary data on policy outputs were obtained through evaluations and activity reports provided by implementing actors. Furthermore, in situ implementation field visits of the programs that were still running were conducted by one of the authors. More than 20 semi-structured interviews were conducted with public administrators, implementing actors, and external experts. Interviewees were asked about their perception of the success of the policy. In treating this material, we adopted the ontological position of "incremental perspectivism" (Porter and Shortall 2009), which holds that pure objective evaluation of implementation success does not exist and, therefore, policy analysis must be based on a critical appraisal of the various perspectives held by stakeholders.

Finally, we explored the reasons that limited tractability. The same set of interviewees was also asked whether the implementation process came up against any obstacles, and why certain goals could not be reached. In the case of the program in Maharashtra described below, one of the authors participated in a stakeholder meeting where limiting factors to the implementation were discussed. Field visits were also used from this perspective. The data were collected in situ, in the first half of 2011, as a part of a larger research project on barriers to adaptation policy processes in several countries.

\section{RESULTS}

\section{India}

Context

India is often considered to be one of the most vulnerable countries to climate change (Brenkert and Malone 2005). India is also notorious for its difficulties in efficiently implementing environmental policies (Greenstone and Hanna 2011), which are at least partially related to the size of its territory, the size and heterogeneity of its population, and its institutional complexity (Lijphart 1996). India formulated its national policy on adaptation in 2008 (Government of India 2008). However, as the Ministry of Environment stated:

India has yet to draw up programs aimed exclusively at addressing critical vulnerabilities to climate change. In other words, India does not implement any adaptation schemes, per se, but has made substantial efforts to integrate adaptation into development schemes (Rajasree 2008). 
Most of the policy actions that explicitly tackle adaptation are being implemented by civil society organizations with some level of involvement and support from the Indian central government and states authorities. Among these, The Swiss Agency for Cooperation and Development's Vulnerability and Adaptation program, or V\&A program, which started as early as 2005 in Rajasthan and, to a lesser extent, the Watershed Organisation Trust's (WOTR) Climate Change Adaptation program of 2009 in Maharashtra, can be considered pioneer interventions.

\section{Problem and goal definition}

The two programs depict the policy problem in a similar way and include elements of the CCA, CVA, and VCA framings. Baseline climate conditions in the semi-arid regions of India are characterized by low annual rainfall (between 400-800 $\mathrm{mm}$; Bruderle and Schwank 2009); both policies insist that, because of poverty and current unsustainable resource management, soil erosion and water scarcity are causing crop productivity reduction or even crop failure, thereby threatening farmers' livelihoods in rain-fed areas. In addition to this societal problematic, the high interannual variability of monsoon intensity and its consequent drought risks also affect livelihoods. Finally, climate change is expected to further aggravate water scarcity and soil erosion because precipitation is projected to become more erratic with heavier extreme rainfall events and longer intermittent warm and dry gaps.

To address this situation, the V\&A program intended to "secure the livelihoods of rural poor and vulnerable communities by promoting adaptation measures that enhance their capacity to better cope with adverse impacts of climate change and by improving their disaster preparedness" (SDC 2005); whereas the aim of the WOTR program is to "have capacitated and empowered rural communities effectively adapted to climate change impact and integrated disaster risk reduction strategies in development programmes" (SDC 2009). Both policies state the intention to: generate the capacity to deal with the impacts of climate change (CCA), develop solutions to address climate variability (CVA), and contribute to "empowering" target groups (VCA; see Tables 3 and 4).

\section{Implementation}

The tractability of the CCA and CVA was comparatively limited in both cases; few outputs could be produced, and they mostly consisted of informational measures that had little impact on the policy problem. Several limiting factors explain this situation. First, given the lack of adaptive capacity in the context of implementation, basic infrastructures for water harvesting and distribution were lacking. Therefore, extremely positive outcomes could be generated with very simple interventions in terms of natural resource management that could be made independently of any predictions of future climate change impacts. Hence, implementation actors perceived CCA-related measures as far less salient:

Climate change adaptation is an abstract concept, which is very, very difficult to be communicated to farmers-a view which some field staff also take. The farmer has so many more powerful short term constraints. Pumping electricity is often unavailable; farm gate prices are like playing casino.

Uncertainty, related to the prediction of the scope and direction of regional climate change, also acted as a limiting factor. For instance, the V\&A program, which principally addressed risks related to increasing drought and water scarcity, was confronted with one of the worst flood situation in recorded history in its second year of implementation in 2006 (Jayan 2012). This weakened the feeling among stakeholders that long-term climate change anticipation was possible or necessary.

Outputs directed at CVA, such as the installation of agrometeorological information systems, were given lower priority, or implemented only as a test in the case of the V\&A program. This cannot be explained solely by the lesser amount of attention devoted to climate variability, given that implementation actors and farmers were generally fully aware of the risks related to drought, for instance. It must also be explained by the lack of capacity of existing strategies or infrastructure aimed at disaster risk reduction in the intervention area. This forced implementing actors to start from scratch when attempting to implement anticipatory disaster risk strategies, which prevented them from producing anything more than piecemeal interventions. Hence, both policies failed to introduce consistent anticipatory risk strategies. The WOTR program performed better in terms of the density and impacts of outputs produced, which we explain by the better organizational capacities available in the area of implementation.

In both implementation processes, the VCA framing was more tractable: more outputs were produced which exerted immediate and positive impacts on target groups. However, weak intra- and inter-policy coordination limited tractability in the case of the V\&A program. Indeed, the V\&A program mainly produced watershed-based interventions, such as soil treatments or the renovation and construction of water harvesting and stocking structures (Bruderle 2009, Bruderle and Chakravarti 2009, Bruderle and Schwank 2009, Bruderle et al. 2009a,b, Nambi and Balasubramanian 2009). Because these outputs effectively enhance water availability and soil fertility, there is little doubt that they contribute to improving the livelihoods of farmers by raising crop productivity. However, no intra-policy coordination mechanisms were produced that would ensure that the benefits generated by the 
Table 3. Summary of V\&A program and analysis of results.

\begin{tabular}{|c|c|c|c|c|}
\hline Problem & Goals & Outputs & Tractability & Limiting factors \\
\hline $\begin{array}{l}\text { CCA } \\
\text { Reduction in available run- } \\
\text { offs; increased water scarcity } \\
\text { in river basin; decrease in } \\
\text { groundwater levels }\end{array}$ & $\begin{array}{l}\text { Promote adaptation } \\
\text { measures that build and } \\
\text { enhance capacity to better } \\
\text { cope with adverse impacts of } \\
\text { climate change }\end{array}$ & $\begin{array}{l}\text { Information: awareness } \\
\text { campaign on climate change } \\
\text { impacts }\end{array}$ & $\begin{array}{l}\text { Low: few outputs that are } \\
\text { limited to signaling the } \\
\text { problem }\end{array}$ & $\begin{array}{l}\text { Lack of capacity; low issue } \\
\text { salience and limited support } \\
\text { of implementation actors; } \\
\text { uncertainty }\end{array}$ \\
\hline $\begin{array}{l}\text { CVA } \\
\text { Arid areas with high rainfall } \\
\text { variability; extreme } \\
\text { temperatures and events cause } \\
\text { frequent crop failures }\end{array}$ & $\begin{array}{l}\text { Improve disaster } \\
\text { preparedness }\end{array}$ & $\begin{array}{l}\text { Information: training } \\
\text { selected community } \\
\text { members in disaster risk } \\
\text { management } \\
\text { Economic means: } \\
\text { introduction of test } \\
\text { agrometeorological } \\
\text { information system }\end{array}$ & $\begin{array}{l}\text { Low: piecemeal } \\
\text { implementation of measures; } \\
\text { failure to introduce } \\
\text { anticipatory risk-reduction or } \\
\text { insurance scheme }\end{array}$ & Lack of capacity \\
\hline $\begin{array}{l}\text { VCA } \\
\text { Extreme sensitivity to water } \\
\text { availability that threatens food } \\
\text { security, ecosystem quality, } \\
\text { and livelihoods of rural } \\
\text { households }\end{array}$ & $\begin{array}{l}\text { Secure livelihoods of rural } \\
\text { poor and vulnerable } \\
\text { communities }\end{array}$ & $\begin{array}{l}\text { Information: water } \\
\text { budgeting exercises } \\
\text { Economic means: } \\
\text { application of silt to field for } \\
\text { enhanced soil water retention } \\
\text { capacity; treatment of } \\
\text { alkaline soils; renovation and } \\
\text { upgrading of water } \\
\text { harvesting and stocking } \\
\text { structures }\end{array}$ & $\begin{array}{l}\text { Medium: outputs increase } \\
\text { livelihoods, through } \\
\text { intensification in short-term } \\
\text { ecosystem delivery. } \\
\text { However, no mechanisms in } \\
\text { place to ensure that this will } \\
\text { translate into patterns of } \\
\text { agricultural development } \\
\text { that are less vulnerable to } \\
\text { climate change }\end{array}$ & $\begin{array}{l}\text { Weak intra-policy } \\
\text { coordination between the } \\
\text { goals of improving } \\
\text { livelihoods and of reducing } \\
\text { climate change vulnerability; } \\
\text { conflicts in inter-policy } \\
\text { coordination with the national } \\
\text { agricultural policy }\end{array}$ \\
\hline
\end{tabular}

V\&A program would also contribute to decreasing vulnerability to climate change. Indeed, temporary increases in water availability will turn out to be purely beneficial in terms of vulnerability if such gains are not compensated for by increasing water demand and land use. Yet farmers' behavior is still influenced by India's national agricultural policy, which has historically focused on input-intensive farming (Kerr 1996, Chand 2005, Narayan 2012). This causes an inter-policy conflict with the V\&A program which tries to decrease vulnerability through sustainable resource management. Studies conducted in villages where similar watershed treatments were previously carried out showed that, in some cases, farmers used water benefits to run supplementary cash crops and started to use seeds that had a high yield potential but were more demanding of inputs such as water and fertilizers and less resistant to heat (Rao 2011). In these cases, new agricultural practices compensated for the ecosystem benefits of the policy intervention, an outcome that can hardly be described as a success in terms of reducing vulnerability to climate change in a context where precipitation is predicted to become more erratic.

The outputs produced by the WOTR program in relation to the VCA framing led to better outcomes precisely because the goal of improving livelihoods was better coordinated with the objective of reducing climate change vulnerability. Outputs were produced to ensure that the benefits brought by natural resource management would not be mitigated by increasing water demand and land use. "Low external input sustainable agriculture" (LEISA) was developed in the implementation area. Farmers were prompted to use water benefits to increase their production and incomes in a climate-friendly way; exploitation of supplementary crops would have to be based preferentially on the use of local seeds that are heat resistant and well adapted to local conditions, whereas the cultivation of new crops that require large amounts of water and fertilizers should be minimized. The principle obstacle to the success of the VCA framing in the WOTR program also lies in the difficulty of overcoming the challenge of inter-policy coordination with the national agricultural policy, which would imply regulating potential conflicts by convincing farmers to adopt and sustain these low-input patterns of agriculture in a policy context where productivity is highly valued.

\section{Switzerland}

\section{Context}

In contrast to India, Switzerland is often considered as one of the countries that are least vulnerable to climate change; for instance, it is ranked fourth on the GAIN Index vulnerability scale. However, rural and mountainous areas such as the "Alpes Vaudoises," as well as certain economic activities such 
Table 4. Summary of WOTR program and analysis of results.

\begin{tabular}{|c|c|c|c|c|}
\hline Problem & Goals & Outputs & Tractability & Limiting factors \\
\hline \multicolumn{5}{|l|}{ CCA } \\
\hline $\begin{array}{l}\text { Increased risk of rainfall } \\
\text { variability, water shortages, } \\
\text { and droughts }\end{array}$ & $\begin{array}{l}\text { To have communities } \\
\text { effectively adapted to } \\
\text { climate change }\end{array}$ & $\begin{array}{l}\text { Information: training on } \\
\text { climate change impacts; } \\
\text { organization of educational } \\
\text { events }\end{array}$ & $\begin{array}{l}\text { Low: very few outputs, } \\
\text { limited to awareness raising } \\
\text { and educational measures }\end{array}$ & $\begin{array}{l}\text { Lack of capacity; low issue } \\
\text { salience and limited support } \\
\text { by implementation actors; } \\
\text { uncertainty }\end{array}$ \\
\hline \multicolumn{5}{|c|}{ 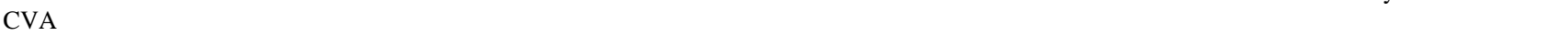 } \\
\hline $\begin{array}{l}\text { Frequent extreme events such } \\
\text { as flash floods }\end{array}$ & $\begin{array}{l}\text { To have integrated disaster } \\
\text { risk-reduction strategies }\end{array}$ & $\begin{array}{l}\text { Information: training in } \\
\text { disaster risk reduction; } \\
\text { establishment of risk } \\
\text { reduction protocols } \\
\text { Economic means: } \\
\text { development of } \\
\text { agrometeorological services; } \\
\text { implementation of } \\
\text { Automated Weather Station } \\
\text { (AWS) }\end{array}$ & $\begin{array}{l}\text { Medium: piecemeal } \\
\text { implementation of measures; } \\
\text { failure to introduce } \\
\text { anticipatory risk-reduction or } \\
\text { insurance scheme }\end{array}$ & Lack of capacity \\
\hline \multicolumn{5}{|l|}{ VCA } \\
\hline $\begin{array}{l}\text { Land degradation, together } \\
\text { with unsustainable resource } \\
\text { exploitation, which leads to } \\
\text { severe depletion of land, } \\
\text { water, and biomass resources }\end{array}$ & $\begin{array}{l}\text { To have built capacity in, } \\
\text { and empowered, rural } \\
\text { communities }\end{array}$ & $\begin{array}{l}\text { Information: training in } \\
\text { biodiversity conservation, } \\
\text { crop density management, } \\
\text { water budgeting; } \\
\text { demonstrations of organic } \\
\text { farming practices Economic } \\
\text { means: soil and water } \\
\text { conservation measures; } \\
\text { creation of Farmers Field } \\
\text { Schools; introduction of, and } \\
\text { training in, low external } \\
\text { input sustainable agriculture } \\
\text { (LEISA); software } \\
\text { introduction for calculating } \\
\text { water and irrigation } \\
\text { requirements; afforestation }\end{array}$ & $\begin{array}{l}\text { High: outputs increase } \\
\text { ecosystem delivery and } \\
\text { contribute to climate change } \\
\text { vulnerability reduction by } \\
\text { introducing more sustainable } \\
\text { and resilient patterns of } \\
\text { agriculture }\end{array}$ & $\begin{array}{l}\text { Conflict of inter-policy } \\
\text { coordination with national } \\
\text { agricultural policy }\end{array}$ \\
\hline
\end{tabular}

as winter tourism, are extremely sensitive and exposed to climate change impacts (Organe consultatif sur les changements climatiques 2007, 2008). The situation in the winter tourism sector, and in particular the case of ski-lift companies, was perceived to be increasingly problematic throughout the 1990s. Several years of weak snowfall in the 1990s contributed to raising awareness about risks related to climate change impacts. Studies underlined the fact that a temperature rise and concomitant snowline elevation will threaten a substantial proportion of ski resorts in low-lying areas (under $1500 \mathrm{~m}$ ). Eight of the 17 resorts of the State of Vaud would be considered as "snow unsecured" with a $2^{\circ} \mathrm{C}$ rise in temperature; for a $4^{\circ} \mathrm{C}$ rise, which is likely to occur towards the end of the century, only one resort would stay snow-secured (Abegg et al. 2007, Müller 2011). As a result, a national moratorium was declared on granting public aid to ski-lift companies in 2002, and subnational authorities (cantons) were requested to reframe their support strategies towards regional winter tourism.

\section{Problem and goal definition}

The State of Vaud initiated a reform of its tourism policy as early as 2003; the policy design was inspired by both CCA and VCA framings. Climate change stimuli such as snowline elevation, glacial melting, and temperature increases are labeled drivers for needed policy reforms, along with the endogenous and structural weaknesses that characterize the tourism sector in this region; companies are seen to be too small and fragmented into too many competing entities to hold up to growing national and international competition. Furthermore, they lack the financial resources to invest in upgrading fast-aging and costly winter tourism infrastructure. A lack of capacity to undertake the necessary steps to adapt to both changing climatic and economic conditions is thus described as the root of the policy problem (Furger 2003, Service de l'économie, du logement et du tourisme 2006). However, the design of this policy contains no traces of the CVA framing. We attribute this to the fact that natural variability in rural areas is an extremely old and well recognized issue in Switzerland; it is clearly distinguished from developmental preoccupations and tackled by distinct policies.

Hence, the policy solely aims to create the conditions that would render the tourism sector of the region attractive and competitive in the medium term and focuses on two axes; on 
the one hand, the policy will contribute to confronting the effects of climate change by guaranteeing snow availability and the attractiveness of ski slopes; on the other hand, the objective is to reduce the structural weakness of the sector by reforming the governance structure of existing tourism companies and by inciting them to improve and diversify the tourism offerings (Conseil d'Etat du Canton de Vaud 2009).

\section{Implementation}

Similar to our Indian cases, the implementation of policy outputs directed at VCA was more successful than for CCA. The implementing agency provided subsidies, loans, and direct investment to tourism companies in exchange for their agreement to initiate mergers to increase their size, capital, and influence on the global market. Public resources were invested in the creation of a new steering committee bringing together tourism entrepreneurs, experts, and public authorities; this was tasked with creating a strategy that would coordinate the development of the tourism sector of the whole region. Existing winter tourism infrastructure was renovated through public funding, and public transportation options for accessing winter resorts were enhanced. These outputs contribute to reducing the economic vulnerability of the tourism sector and will have positive effects, independent of future climate change impacts. Limiting factors primarily concerned private-sector resistance to state involvement in merging historically competing companies, and to the diversification of tourism activities; this was sometimes perceived to be a move away from the tradition of winter tourism in these alpine regions. However, such resistance could be overcome through the "carrot and stick" approach (Conseil d'Etat du Canton de Vaud 2009) that prevailed throughout the implementation process. (See Table 5.)

Implementing policy outputs related to the CCA framing was subject to many more limitations. Implementing actors proposed to secure the snow cover through artificial snowmaking, the extension of ski slopes towards higher altitudes, and the connection of existing slope areas to constitute a bigger ski domain with better access to the highest and more snow-exposed ski slopes. However, supplementary snowmaking facilities could only be installed on some sections of the ski slopes, and plans to enhance the connections of the ski slopes to a nearby high-altitude glacier by building new ski lifts have been delayed because of numerous blockages. First, the present economic vulnerability of the tourism sector was perceived to be a more urgent issue than that of future climate conditions, which explains why snowmaking and the extension of the skiing area were given lower priority. Second, snowmaking and ski area-extension are cost-, time-, and energy-intensive activities, as well as being environmentally damaging. Whether the benefits of such measures will outweigh the costs is dependent on how long future climate conditions, notably temperature rises, will allow artificial snowmaking to be profitable and effective against a rising snowline elevation. Such calculations can only be made through precise snow models and climate predictions at the local level that are as yet not available (Rebetez and Serquet 2010). Hence, the decision to invest heavily in snowmaking, which was first expected in 2012, has been delayed. Even if studies were to conclude that artificial snowmaking and skiarea extensions are viable options in the medium term, the rather restrictive environmental prescriptions contained in spatial planning laws and nature and landscape protection policies will cause inter-policy conflicts in the full implementation of such outputs. Finally, the probable longterm obligation for most of these low-lying resorts to switch definitively to summer tourism, and widespread public concern about environmental protection, will make the implementation of outputs directed at CCA difficult, as demonstrated by the strong social and political opposition that has already been expressed in the public arena and in the media to the transformational measures (Modoux 2012).

\section{DISCUSSION AND CONCLUSION}

Taking a broader view, Table 6 summarizes our results, and what we see as the main determinants of the variation in the tractability of adaptation framings across and within cases.

We found that the tractability of the CCA framing is lower than the VCA framing in each of our cases, even though adaptive capacity varies greatly between Switzerland and India. This finding is interesting for two reasons. First, it demonstrates that a lack of adaptive capacity is not sufficient for explaining the implementation deficit related to CCA. Second, we found that the low tractability of CCA is explained by different limiting factors depending on the context. In the example of the rural development policy for the Alpes Vaudoises, where adaptive capacity is high, the widespread social and political resistance to transformational measures as well as the inter-policy conflict with existing environmental regulations primarily explains the implementation deficit, whereas in the WOTR and V\&A programs, the lack of adaptive capacity and the lower salience of the CCA framing are more explicative.

For comparability reasons, we did not include the CVA framing in Table 6, as it was absent from the policy examined in Switzerland. However, in both Indian cases, the tractability of the CVA framing was low, which we explain by the lack of capacity related to disaster risk reduction in the areas of implementation. This finding actually reflects the gap between the sensitivity and exposure to climate events in rural areas in India, and the state and sub state disaster risk policies which are often limited to the delivery of urgency relief measures and have failed to provide more long-term and proactive solutions, especially in poor rural areas (Prabhakar and Shaw 2008). In this policy context, implementing actors face the challenge of trying to develop strategies to deal with climate variability although the needed infrastructure is often absent. 
Table 5. Summary of the Alpes Vaudoises rural development policy and analysis of results.

\begin{tabular}{|c|c|c|c|c|}
\hline Problem & Goals & Outputs & Tractability & Limiting factors \\
\hline \multicolumn{5}{|l|}{$\mathrm{CCA}$} \\
\hline $\begin{array}{l}\text { Temperature warming; } \\
\text { snowline elevation; snowpack } \\
\text { diminution; glacier melting }\end{array}$ & $\begin{array}{l}\text { To guarantee sufficient snow } \\
\text { cover and attractiveness of } \\
\text { the ski slopes }\end{array}$ & $\begin{array}{l}\text { Information: modeling of } \\
\text { future snow availability } \\
\text { Economic means: subsidies } \\
\text { for new snowmaking } \\
\text { installations } \\
\text { Regulation: public } \\
\text { authorization for } \\
\text { constructing new } \\
\text { snowmaking installations }\end{array}$ & $\begin{array}{l}\text { Low: piecemeal installation } \\
\text { of snowmaking equipment; } \\
\text { delay in attempt to extend } \\
\text { ski-slope area, by connecting } \\
\text { resorts, and towards higher } \\
\text { altitudes }\end{array}$ & $\begin{array}{l}\text { Lack of inter-policy } \\
\text { coordination with spatial } \\
\text { planning, and with nature and } \\
\text { landscape protection policy; } \\
\text { social and political resistance } \\
\text { to transformational measures; } \\
\text { lack of issue salience; lack of } \\
\text { capacity; uncertainty }\end{array}$ \\
\hline \multicolumn{5}{|l|}{ VCA } \\
\hline $\begin{array}{l}\text { Poor financial situation for } \\
\text { ski-lift companies; } \\
\text { international and regional } \\
\text { economic competition; } \\
\text { economic sluggishness and } \\
\text { stagnation in demand; lacking } \\
\text { or dilapidated modern } \\
\text { tourisism infrastructure }\end{array}$ & $\begin{array}{l}\text { To introduce a single and } \\
\text { strengthened governance } \\
\text { structure for the entire } \\
\text { tourism sector in the Prealps } \\
\text { mountain range; to diversify } \\
\text { tourism offerings }\end{array}$ & $\begin{array}{l}\text { Information: study on } \\
\text { diversification of tourism } \\
\text { Economic means: public } \\
\text { investment in realizing new } \\
\text { tourism infrastructure; } \\
\text { investment in replacing and } \\
\text { renovating existing ski-lift } \\
\text { installations; recapitalization } \\
\text { and financial restructuration } \\
\text { of companies; realization of } \\
\text { new marketing and } \\
\text { communication concepts; } \\
\text { strengthening public } \\
\text { transportation options } \\
\\
\text { Regulation: merging of ski- } \\
\text { lift companies; creation of a } \\
\text { new steering structure for the } \\
\text { promotion and development } \\
\text { of tourism projects }\end{array}$ & $\begin{array}{l}\text { High: reinforcing the } \\
\text { capacity of tourism } \\
\text { companies has positive } \\
\text { outcomes, regardless of } \\
\text { future climate change } \\
\text { impacts }\end{array}$ & $\begin{array}{l}\text { Company resistance to state } \\
\text { intervention }\end{array}$ \\
\hline
\end{tabular}

The VCA framing was revealed to be more tractable regardless of the context. The main challenge to successful implementation that we have identified was the lack of intrapolicy coordination; in this case, between developmental and climate vulnerability reduction objectives. We argue that this is mainly a problem of policy design; there is no systematic link between social-welfare improvement and resilience to climate change and, therefore, special care should be taken regarding how coordination mechanisms can be designed and implemented to ensure that trade-offs are well managed. Intrapolicy coordination appears to be a central issue for a second reason, which is that the only added value of policies inspired from the VCA framing in comparison to business-as-usual development initiatives resides precisely in this capacity to attain both welfare improvement and climate change impact reductions.

Based on these findings, we argue that adaptation policy is caught in a paradox. On the one hand, designing adaptation policies framed as CCA is very desirable; first, as a mean to anticipate the long-term and exceptional effects attributed to climate change in conformity with the prevention principle; and second, because CCA policies better fit the criterion of "additionality," that is, they constitute a real innovation in comparison with existing policies. However, CCA policies are also more likely to face a deficit in implementation, especially in contexts where adaptive capacity is low. Therefore, we argue that there is a major trade-off involved in the choice between designing a policy as CCA, which would have the quality of being innovative and "additional," and as VCA, which would probably be a more tractable option.

This argument has clear implications for adaptation policy making and the question of adaptation finance. The UNFCCC view on adaptation, and the present eligibility rules for adaptation funding, are exerting pressure to implement CCA types of policies by requiring project holders to clearly distinguish between baseline development needs and climate change-related actions (United Nations Development Programme 2010). However, considering the potential inter- 
Table 6. Tractability of adaptation framings within and across cases.

\begin{tabular}{lllll}
\hline \hline & V\&A program & WOTR program & Alpes Vaudoises & Principal causes of variance across cases \\
\hline $\begin{array}{l}\text { Tractability of the CCA } \\
\text { framing }\end{array}$ & Low & Low & Low & $\begin{array}{l}\text { Lack of salience and weak inter-policy } \\
\text { coordination caused tractability to remain } \\
\text { low even though adaptive capacity varied }\end{array}$
\end{tabular}

\begin{tabular}{llll}
$\begin{array}{l}\text { Tractability of the VCA } \\
\text { framing }\end{array}$ & Medium & High & High \\
$\begin{array}{l}\text { Principal causes of variance } \\
\text { within cases }\end{array}$ & $\begin{array}{l}\text { Lack of adaptive } \\
\text { capacity and of } \\
\text { salience of CCA }\end{array}$ & $\begin{array}{l}\text { Lack of adaptive } \\
\text { capacity and of } \\
\text { salience of CCA }\end{array}$ & $\begin{array}{l}\text { Inter-policy coordination } \\
\text { conflicts related to CCA } \\
\text { Lack of salience (social and } \\
\text { political resistance) of CCA }\end{array}$ \\
\hline
\end{tabular}

policy coordination conflicts between CCA measures and sustainability policies, in addition to the current uncertainty that characterizes climate impact prediction at the regional level, VCA policies that manage to lessen human pressures on natural resources exposed to climate risks, although probably less additional, will in every instance generate positive outcomes and should be considered as a win-win adaptive strategy (Doria et al. 2009).

From a theoretical perspective, we think that our research, which links the concept of adaptation framing with the study of implementation processes, sheds new light on the claim made by Adger et al. (2009) that adaptation goals might be connected to specific limits, and that policies can be designed according to the different framings of adaptation that we have detailed using our own typology. We have used case studies to demonstrate that these framings are related to different limiting factors in implementation. We also think that our research stresses the need to focus more on the actual effects of adaptation policy. Many studies have sought to measure progress on adaptation by simply identifying and counting policy actions (Tompkins et al. 2010) or barriers related to adaptation (Moser and Ekstrom 2010), but avoided the question of the likely outcomes of present efforts to adapt to climate change through public policies (see: Ford et al. 2013).

Several limitations that are related to our theoretical approach and methods must be mentioned. First, by focusing on implementation and endorsing the stage view of the policy process that is prominent in adaptation policy studies (see Burton et al. 2002, Gagnon-Lebrun and Agrawala 2006, Moser and Ekstrom 2010), we are also subject to the well-known criticism that a clear and linear division between the programming and implementation phases might poorly account for the more complex reality of policy making (Nakamura 1987, Sabatier 1999). Barriers to adaptation policy might occur well before implementation, for instance, during the agenda-setting phase. However, we would argue that the current reality of adaptation policy making, namely that adaptation policies are being designed by government and public administrations but that implementation lags behind, speaks in favor of refocusing on implementation.

Finally, an extremely large number of variables can possibly affect implementation outcomes (Goggin 1986, O'Toole 2004), and through our small " $n$ " design, we cannot claim to have covered all of the factors that might prevent the successful implementation of adaptation policy. Other characteristics of policy design such as the target group selection (Schneider and Sidney 2009), or other dimensions of governance processes such as the role of agency and leadership in actor coalitions (Meijerink and Stiller 2013), or the types of networks and modes of interactions involved (Juhola and Westerhoff 2011) need to be investigated to fully understand or perhaps even fill the implementation deficit of adaptation policy.

Responses to this article can be read online at: http://www.ecologyandsociety.org/issues/responses. php/5965

\section{Acknowledgments:}

This research was realized thanks to the support of the Swiss National Science Foundation (SNF) and the Swiss Agency for Development and Cooperation (SDC). We would also like to thank Robbert Biesbroek, Frans Berkhout, Guillaume De Buren, Konstantin Gavazov, Michael Howlett, Peter May, Daniel Mazmanian, Nils Moussu, Rémi Schweizer, Katrien Termeer, and the two anonymous reviewers for their comments and insights.

\section{LITERATURE CITED}

Abegg, B., S. Jetté Nantel, F. Crick, and A. de Montfalcon. 2007. Climate change impacts and adaptation in winter tourism. Pages 25-58 in S. Agrawala, editor. Climate change in the European Alps: adapting winter tourism and natural 
hazards management. Organisation for Economic Cooperation and Development (OECD), Paris, France.

Adger, W. N., S. Agrawala, M. M. Q. Mirza, C. Conde, K. O'Brien, J. Pulhin, R. Pulwarty, B. Smit, and K. Takahashi. 2007. Assessment of adaptation practices, options, constraints and capacity. Pages 717-744 in B. Metz, O. R. Davidson, P. R. Bosch, R. Dave, and L. A. Meyer, editors. Climate change 2007: mitigation. Contribution of working group III to the fourth assessment report of the Intergovernmental Panel on Climate Change. Cambridge University Press, Cambridge, UK.

Adger, W. N., S. Dessai, M. Goulden, M. Hulme, I. Lorenzoni, D. R. Nelson, L. O. Naess, J. Wolf, and A. Wreford. 2009. Are there social limits to adaptation to climate change? Climatic Change 93(3-4):335-354. http://dx.doi.org/10.1007/ s10584-008-9520-Z

Anckar, C. 2008. On the applicability of the most similar systems design and the most different systems design in comparative research. International Journal of Social Research Methodology 11(5):389-401. http://dx.doi. org/10.1080/13645570701401552

Bachrach, P., and M. S. Baratz. 1963. Decisions and nondecisions: an analytical framework. The American Political Science Review 57:632-642. http://dx.doi. org/10.2307/1952568

Bardach, E. 1977. The implementation game: what happens after a bill becomes a law. The MIT Press, Cambridge, Massachusetts, USA.

Barrett, S. M. 2004. Implementation studies: time for a revival? Personal reflections on 20 years of implementation studies. Public Administration 82(2):249-s62.

Bemelmans-Videc, M. L., R. C. Rist, and E. Vedung, editors. 1998. Carrots, sticks and sermons: policy instruments and their evaluation. Transaction, Piscataway, New Jersey, USA.

Biesbroek, G. R., J. Klostermann, C. Termeer, and P. Kabat. 2013. On the nature of barriers to climate change adaptation. Regional Environmental Change 13(5):1119-1129. http://dx. doi.org/10.1007/s10113-013-0421-y

Biesbroek, G. R., R. J. Swart, T. R. Carter, C. Cowan, T. Henrichs, H. Mela, M. D. Morecroft, and D. Rey. 2010. Europe adapts to climate change: comparing national adaptation strategies. Global Environmental Change 20(3):440-450. http://dx.doi.org/10.1016/j.gloenvcha.2010.03.005

Brenkert, A. L., and E. L. Malone. 2005. Modeling vulnerability and resilience to climate change: a case study of India and Indian states. Climatic Change 72(1-2):57-102. http://dx.doi.org/10.1007/s10584-005-5930-3
Brooks, N. 2003. Vulnerability, risk and adaptation: a conceptual framework. Working paper 38. Tyndall Centre for Climate Change Research, University of East Anglia, Norwich, UK.

Bruderle, A. 2009. Pasture land development: case study. Climate change: vulnerability and adaptation. Experiences from Rajasthan and Andra Pradesh. Swiss Agency for Cooperation and Development (SDC), Hyderabad, India.

Bruderle, A., and D. Chakravarti. 2009. Community based institutions. Climate change: vulnerability and adaptation experiences from Rajasthan and Andra Pradesh. Swiss Agency for Cooperation and Development (SDC), Hyderabad, India.

Bruderle, A., D. Chakravarti, and J. Plakkoottam. 2009a. Water resource management. Climate change: vulnerability and adaptation experiences from Rajasthan and Andra Pradesh. Swiss Agency for Cooperation and Development (SDC), Hyderabad, India.

Bruderle, A., S. Prasad, and S. Roy. 2009b. The system of rice intensification. Climate change: vulnerability and adaptation experiences from Rajasthan and Andra Pradesh. Swiss Agency for Cooperation and Development (SDC), Hyderabad, India.

Bruderle, A. and O. Schwank. 2009. Introduction. Climate change: vulnerability and adaptation experiences from Rajasthan and Andra Pradesh. Swiss Agency for Cooperation and Development (SDC), Hyderabad, India.

Burton, I., S. Huq, B. Lim, O. Pilifosova, and E. L. Schipper. 2002. From impacts assessment to adaptation priorities: the shaping of adaptation policy. Climate Policy 2:145-159.

Campbell, J. L. 2002. Ideas, politics, and public policy. Annual Review of Sociology 28:21-38. http://dx.doi.org/10.1146/ annurev.soc.28.110601.141111

Chand, R. 2005. Overview. Pages 1-18 in R. Chand, editor. India's agricultural challenges: reflections on policy, technology and other issues. Consortium for Trade and Development (CENTAD), New Delhi, India.

Commission of the European Communities. 2007. Green paper from the Commission to the Council, the European Parliament, the European Economic and Social Committee and the Committee of the Regions. Adapting to climate change in Europe-options for EU action. Commission of the European Communities, Brussels, Belgium.

Commission of the European Communities. 2009. White paper. Adapting to climate change: towards a European framework for action. Commission of the European Communities, Brussels, Belgium. 
Conseil d'Etat du Canton de Vaud. 2009. Rapport du Conseil d'Etat au Grand Conseil sur le postulat d'Olivier Feller et consorts demandant au Conseil d'Etat d'élaborer un plan d'action pour faire face au réchauffement climatique dans les stations d'hiver Vaudoises. Lausanne, Switzerland.

Doria, M., E. Boyd, E. L. Tompkins, and W. N. Adger. 2009. Using expert elicitation to define successful adaptation to climate change. Environmental Science and Policy 12:810819. http://dx.doi.org/10.1016/j.envsci.2009.04.001

Dovers, S. R., and A. A. Hezri. 2010. Institutions and policy processes: the means to the ends of adaptation. Wiley Interdisciplinary Reviews: Climate Change 1(2):212-231. http://dx.doi.org/10.1002/wcc.29

Dupuis, J. and G. R. Biesbroek. 2013. Comparing apples and oranges: the dependent variable problem in comparing and evaluating climate change adaptation policies. Global Environmental Change http://dx.doi.org/10.1016/j. gloenvcha.2013.07.022

Dupuis, J., and P. Knoepfel. 2011. Les barrières à la mise en œuvre des politiques d'adaptation au changement climatique: le cas de la Suisse. Swiss Political Science Review 17(2):188219.

Eakin, H., E. L. Tompkins, D. R. Nelson, and J. M. Anderies. 2009. Hidden costs and disparate uncertainties: trade-offs involved in approaches to climate policy. Pages 212-226 in W. N. Adger, I. Lorenzoni, and K. O'Brien, editors. Adapting to climate change: thresholds, values, governance. Cambridge University Press, New York, New York, USA.

Economics of Climate Adaptation Working Group (ECA). 2009. Shaping climate-resilient development: a framework for decision-making. ClimateWorks Foundation, Global Environment Facility, European Commission, McKinsey \& Company, The Rockefeller Foundation, Standard Chartered Bank, and Swiss Re. http://ec.europa.eu/development/icenter/repository/ ECA Shaping Climate Resilent Development.pdf

Eriksen, S., P. Aldunce, C. S. Bahinipati, R. D. A. Martins, J. I. Molefe, C. Nhemachena, K. O'Brien, F. Olorunfemi, J. Park, L. Sygna, and K. Ulsrud. 2011. When not every response to climate change is a good one: identifying principles for sustainable adaptation. Climate and Development 3:7-20. http://dx.doi.org/10.3763/cdev.2010.0060

Ford, J., L. Berrang-Ford, and J. Paterson. 2011. A systematic review of observed climate change adaptation in developed nations. Climatic Change 106(2):327-336. http://dx.doi. org/10.1007/s10584-011-0045-5

Ford, J. D., L. Berrang-Ford, and A. Lesnikowski. 2013. How to track climate change adaptation: a typology of approaches for national-level application. Ecology and Society 18(3): 40 [online] URL: http://www.ecologyandsociety.org/vol18/iss3/ $\underline{\operatorname{art} 40 /}$
Furger, P. 2003. Analyse stratégique sur l'organisation et la gestion des sociétés de remontées mécaniques des Alpes vaudoises: l'avenir des remontées mécaniques des Alpes Vaudoises. Service de l'économie, du logement et du tourisme (SELT), Lausanne, Switzerland.

Füssel, H. M. 2010. How inequitable is the global distribution of responsibility, capability, and vulnerability to climate change: a comprehensive indicator-based assessment. Global Environmental Change 20(4):597-611. http://dx.doi.org/10.1016/ j.gloenvcha.2010.07.009

Füssel, H. M., S. Hallegatte, and M. Reder. 2012. International adaptation funding. Pages 311-330 in O. Edenhofer, J. Wallacher, H. Lotze-Campen, M. Reder, B. Knopf, and J. Müller, editors. Climate change, justice and sustainability: linking climate and development policy. Springer, Heidelberg, Germany. http://dx.doi.org/10.1007/978-94-007-4540-7 29

Gagnon-Lebrun, F. and S. Agrawala. 2006. Progress on adaptation to climate change in developed countries: an analysis of broad trends. Organisation for Economic Cooperation and Development (OECD), Paris, France.

Global Environmental Facility (GEF). 2010. Financing adaptation action. GEF Secretariat, Washington, D.C., USA. http://www.thegef.org/gef/pubs/financing-adaptation-action

Goggin, M. L. 1986. The "too few cases/too many variables" problem in implementation research. Political Research Quarterly 39(2):328-347. http://dx.doi.org/10.1177/106591$\underline{298603900210}$

Government of India. 2008. National action plan on climate change. Prime Minister's Council on Climate Change, Government of India, Delhi, India.

Greenstone, M., and R. Hanna. 2011. Environmental regulations, air and water pollution, and infant mortality in India. Working paper 17210. National Bureau of Economic Research (NBER), Cambridge, Massachusetts, USA.

Hajer, M., and W. Versteeg. 2005. A decade of discourse analysis of environmental politics: achievements, challenges, perspectives. Journal of Environmental Policy and Planning 7(3) 175-84.

Hill, M., and P. Hupe. 2003. The multi-layer problem in implementation research. Public Management Review 5:471490. http://dx.doi.org/10.1080/1471903032000178545

Hjern, B., and C. Hull. 1982. Implementation research as empirical constitutionalism. European Journal of Political Research 10(2):105-15.

Hisschemöller, M., and R. Hoppe. 1995. Coping with intractable controversies: the case for problem structuring in policy design and analysis. Knowledge and Policy 8:40-60. http://dx.doi.org/10.1007/BF02832229 
Hoppe, R., H. Van de Graaf, and A. van Dijk. 1987. Implementation research and policy design: problem tractability, policy theory, and feasibility testing. International Review of Administrative Sciences 53:581-604. http://dx.doi. org/10.1177/002085238705300407

Holzinger, K., C. Knill, and T. Sommerer. 2011. Is there convergence of national environmental policies? An analysis of policy outputs in 24 OECD countries. Environmental Politics 20(1):20-41.

Howlett, M., and M. Ramesh. 1995. Studying public policy: policy cycles and policy subsystems. Oxford University Press, Toronto, Ontario, Canada.

Hulme, P. E. 2005. Adapting to climate change: is there scope for ecological management in the face of a global threat? Journal of Applied Ecology (42)784-94.

Hupe, P. L. 2011. The thesis of incongruent implementation: revisiting Pressman and Wildavsky. Public Policy and Administration 26(1):63-80. http://dx.doi.org/10.1177/0952$\underline{076710367717}$

Ingram, H., A. L. Schneider, and P. DeLeon. 2007. Social construction and policy design. Pages 93-126 in P. Sabatier, editor. Theories of the policy process. Westview, Boulder, Colorado, USA.

Intergovernmental Panel on Climate Change (IPCC). 2007. Glossary of terms used in the IPCC fourth assessment report. Page 976 in M. L. Parry, O. F. Canziani, J. P. Palutikof, P. J. v. d. Linden, and C. E. Hanson, editors. Climate change 2007: impacts, adaptation and vulnerability. Contribution of working group II to the fourth assessment report of the Intergovernmental Panel on Climate Change. Cambridge University Press, Cambridge, UK.

Jayan, T. V. 2012. Floods in western Rajasthan: life after the deluge. Pages 82-89 in E. Prasad, K. J. Joy, S. Paranjape, and S. Vispute, editors. Agony of floods: flood induced water conflicts in India. Forum for Policy Dialogue on Water Conflicts in India, Pune, India.

Juhola, S., E. C. H. Keskitalo, and L. Westerhoff. 2011. Understanding the framings of climate change adaptation across multiple scales of governance in Europe. Environmental Politics 20:445-463. http://dx.doi. org/10.1080/09644016.2011.589571

Juhola, S., and L. Westerhoff. 2011. Challenges of adaptation to climate change across multiple scales: a case study of network governance in two European countries. Environmental Science and Policy 14(3):239-47.

Kates, R. W., W. R. Travis, and T. J. Wilbanks. 2012. Transformational adaptation when incremental adaptations to climate change are insufficient. Proceedings of the National Academy of Sciences 109:7156-7161. http://dx.doi.org/10.1073/ pnas. 1115521109

Kerr, J. M. 1996. Sustainable development of rainfed agriculture in India. International Food Policy Research Institute, Washington, D.C., USA.

Keskitalo, E. C. H. 2010. Developing adaptation policy and practice in Europe: multi-level governance of climate change. Springer, Dordrecht, Netherlands. http://dx.doi. org/10.1007/978-90-481-9325-7

Knoepfel, P. 1995. New institutional arrangements for the next generation of environmental policy instruments: intra- and interpolicy-co-operation. Pages 150-70 in B. Dente, editor. Environmental policy: in search of new instruments. Kluwer, Dordrecht, The Netherlands.

Lafferty, W., E. and Hovden. 2003. Environmental policy integration: towards an analytical framework. Environmental Politics 12(3):1-22.

Lijphart, A. 1996. The puzzle of Indian democracy: a consociational interpretation. The American Political Science Review 90(2):258-268. http://dx.doi.org/10.2307/2082883

Lipsky, M. 2010. Street-level bureaucracy: dilemmas of the individual in public services. Russell Sage Foundation, New York, New York, USA.

Malik, K. 2013. Human development report 2013. The rise of the south: human progress in a diverse world. United Nations Development Programme (UNDP), New York, New York, USA.

Marsh, D., and A. McConnell. 2010. Towards a framework for establishing policy success. Public Administration 88 (2):564-583. http://dx.doi.org/10.1111/j.1467-9299.2009.01803. $\underline{\mathrm{X}}$

Matland, R. E. 1995. Synthesizing the implementation literature: the ambiguity-conflict model of policy implementation. Journal of Public Administration Research and Theory 5(2):145-174.

Mceldowney, J. J. 1997. Policy evaluation and the concepts of deadweight and additionality. Evaluation 3(2):175-188. http://dx.doi.org/10.1177/135638909700300204

McGray, H., A. Hammill, R. Bradley, E. Schipper, and J. Parry. 2007. Weathering the storm: options for framing adaptation and development. World Resources Institute (WRI), Washington, D.C., USA.

Meijerink, S., and S. Stiller. 2013. What kind of leadership do we need for climate adaptation? A framework for analyzing leadership objectives, functions, and tasks in climate change 
adaptation. Environment and Planning C: Government and Policy 31(2):240-56

Miller, C. A. 2000. The dynamics of framing environmental values and policy: four models of societal processes. Environmental Values 9:211-233. http://dx.doi. org/10.3197/096327100129342047

Modoux, F. 2012. Alpes vaudoises, le grand chambardement. Le Temps. Edipresse, Geneva, Switzerland.

Moser, S. C., and J. A. Ekstrom. 2010. A framework to diagnose barriers to climate change adaptation. Proceedings of the National Academy of Sciences 107(51):22026-22031 http://dx.doi.org/10.1073/pnas.1007887107

Müller, H. 2011. Der Schweizer Tourismus im Klimawandel. State Secretariat for Economic Affairs (SECO), Bern, Switzerland.

Nadel, M. V. 1975. The hidden dimension of public policy: private governments and the policy-making process. The Journal of Politics 37(1):2-34. http://dx.doi.org/10.2307/2128889

Nakamura, R. T. 1987. The textbook policy process and implementation research. Review of Policy Research 7 (1):142-154. http://dx.doi.org/10.1111/j.1541-1338.1987.tb00034. $\underline{\mathrm{X}}$

Nambi, A. A., and T. N. Balasubramanian. 2009. A weatherbased farming model for communities. Climate change: vulnerability and adaptation experiences from Rajasthan and Andra Pradesh. Swiss Agency for Cooperation and Development (SDC), Hyderabad, India.

Narayan, B. S. 2012. Sustainable agricultural development and organic farming in India. Golden Research Thoughts 1

O'Brien, K., S. Eriksen, L. P. Nygaard, and A. Schjolden. 2007. Why different interpretations of vulnerability matter in climate change discourses. Climate Policy 7(1):73-88.

O'Toole, L. J. 2004. The theory-practice issue in policy implementation research. Public Administration 82(2):309329. http://dx.doi.org/10.1111/j.0033-3298.2004.00396.x

Oberthür, S., and H. E. Ott. 1999. The Kyoto protocol: international climate policy for the 21st century. Springer, Berlin, Heidelberg, Germany. http://dx.doi.org/10.1007/978$\underline{-3-662-03925-0}$

Organe consultatif sur les changements climatiques (OcCC). 2007. Klimä̈nderung und die Schweiz 2050. OcCC, Bern, Switzerland.

Organe consultatif sur les changements climatiques (OcCC). 2008. Das Klima ändert-was nun? OcCC, Bern, Switzerland.
Parsons, W. 1995. An introduction to the theory and practice of policy analysis. Edward Elgar, Aldershot, UK.

Pentland, R., J. Theys, and I. Abrol. 1990. Resource use and management. Pages 165-203 in F. Bernthal, E. Dowdeswell, J. Luo, D. Attard, P. Vellinga, and R. Karimanzira, editors. Climate change: the IPCC response strategies. United Nations Environment Programme (UNEP), New York, New York, USA, and the World Meteorological Organization (WMO), Geneva, Switzerland.

Peters, G. B. 2005. The problem of policy problems. Journal of Comparative Policy Analysis 7:349-370. http://dx.doi. org/10.1080/13876980500319204

Pielke, R. A. 2005. Misdefining "climate change": consequences for science and action. Environmental Science and Policy 8:548-561. http://dx.doi.org/10.1016/j.envsci.2005.06.013

Porter, S., and S. Shortall. 2009. Stakeholders and perspectivism in qualitative policy evaluation: a realist reflection. Public Administration 87(2):259-273. http://dx. doi.org/10.1111/j.1467-9299.2008.01735.x

Prabhakar, S. V. R. K., and R. Shaw. 2008. Climate change adaptation implications for drought risk mitigation: a perspective for India. Climatic Change 88(2):113-130. http:// dx.doi.org/10.1007/s10584-007-9330-8

Pressman, J. L., and A. Wildavsky. 1984. Implementation: how great expectations in Washington are dashed in Oakland: or, why it's amazing that federal programs work at all, this being a saga of the Economic Development Administration as told by two sympathetic observers who seek to build morals on a foundation of ruined hopes. University of California Press, Berkeley, California, USA.

Rajasree, R. 2008. Adaptation activities In India. Development Outreach 10:18-21. http://dx.doi.org/10.1596/1020-797X-10-1 18

Rao, K. B. 2011. Agriculture market price fluctuations, changing livestock systems and Vulnerability Connect\#8212; a case of Mhaswandi watershed, Ahmednagar district, Marahstra. Watershed Organisation Trust (WOTR), Pune, India.

Rebetez, M., and G. Serquet. 2010. Changements climatiques: quel avenir pour les destinations touristiques des Alpes et du Jura vaudois. Swiss Federal Institute for Forest, Snow and Landscape Research (WSL), Lausanne, Switzerland.

Rochefort, D. A., and R. W. Cobb. 1994. The politics of problem definition: shaping the policy agenda. University of Kansas Press, Kansas City, USA.

Sabatier, P. 1999. The need for better theories. Pages 19-32 in P. Sabatier, editor. Theories of the policy process. Westview, Boulder, Colorado. 
Schipper, E. L. F. 2006. Conceptual history of adaptation in the UNFCCC process. Review of European Community and International Environmental Law 15:82-92. http://dx.doi. org/10.1111/j.1467-9388.2006.00501.x

Schneider, A., and M. Sidney. 2009. What is next for policy design and social construction theory? Policy Studies Journal 37(1):103-119. http://dx.doi.org/10.1111/j.1541-0072.2008.00298. $\underline{\mathrm{x}}$

Seawright, J., and J. Gerring. 2008. Case selection techniques in case study research. Political Research Quarterly 61(2) 294-308.

Service de l'économie, du logement et du tourisme (SELT). 2006. Rapport sur les axes stratégiques du tourisme vaudois. Canton de Vaud, Lausanne, Switzerland.

Smit, B., O. Pilifosova, I. Burton, R. J. T. Klein, B. Challenger, S. Huq, and G. Yohe. 2001. Adaptation to climate change in the context of sustainable development and equity. Pages 879906 in J. J. McCarthy, O. F. Canziani, N. A. Leary, D. J. Dokken, and K. S. White, editors. Climate change 2001: impacts, adaptation, vulnerability. Contribution of Working Group II to the third assessment report of the Intergovernmental Panel on Climate Change. Cambridge University Press, Cambridge, UK.

Smithers, J. and B. Smit. 1997. Human adaptation to climatic variability and change. Global Environmental Change 7 (2):129-146. http://dx.doi.org/10.1016/S0959-3780(97)00003-4

Swiss Agency for Cooperation and Development (SDC). 2005. Vulnerability assessment and enhancing adaptive capacity to climate change in semi-arid areas in India: a new phase of the project on structural transformation processes/ capacity building in climate change/India. SDC, Bern, Switzerland.

Swiss Agency for Cooperation and Development (SDC). 2009. Proposition de crédit: WOTR-SDC partnership for climate change adaptation. SDC, Dehli, India, and Bern, Switzerland.

Termeer, C., A. Dewulf, and G. Breeman. 2013. Governance of wicked climate adaptation problems. Pages 27-39 in J. Knieling, and W. L. Filho, editors. Climate change governance. Springer, Berlin, Germany.

Tompkins, E. L., W. N. Adger, E. Boyd, S. Nicholson-Cole, K. Weatherhead, and N. Arnell. 2010. Observed adaptation to climate change: UK evidence of transition to a well-adapting society. Global Environmental Change 20(4):627-635. http:// dx.doi.org/10.1016/j.gloenvcha.2010.05.001

Treib, O., H. Bähr, and G. Falkner. 2007. Modes of governance: towards a conceptual clarification. Journal of European Public Policy 14(1):1-20. http://dx.doi. org/10.1080/135017606061071406
Trenberth, K. E., J. T. Houghton, and L. G. M. Filho. 1995. The climate system: an overview. Pages 51-64 in J. T. Houghton, L. G. M. Filho, B. A. Callander, N. Harris, A. Kattenberg, and K. Maskell, editors. Climate change 1995: the science of climate change. Contribution of Working Group I to the second assessment report of the Intergovernmental Panel on Climate Change. Cambridge University Press, Cambridge, UK.

United Nations (UN). 1992. United Nations Framework Convention on Climate Change (UNFCCC). UNFCCC Secretariat, Bonn, Germany.

United Nations Development Programme (UNDP). 2010. A toolkit for designing climate change adaptation initiatives. UNDP, New York, New York, USA.

Urwin, K., and A. Jordan. 2008. Does public policy support or undermine climate change adaptation? Exploring policy interplay across different scales of governance. Global Environmental Change 18:180-191. http://dx.doi.org/10.1016/ j.gloenvcha.2007.08.002

Varone, F., S. Nahrath, D. Aubin, and J. D. Gerber. 2013. Functional regulatory spaces. Policy Sciences 46:1-23.

Ward, N., A. Donaldson, and P. Lowe. 2004. Policy framing and learning the lessons from the UK's foot and mouth disease crisis. Environment and Planning C 22(2):291-306. http://dx. doi.org/10.1068/c0209s

Wellstead, A. M., M. Howlett, M., and J. Rayner. 2013. The neglect of governance in forest sector vulnerability assessments: structural-functionalism and "black box" problems in climate change adaptation planning. Ecology and Society 18(3): 23. http://www.ecologyandsociety.org/vol18/ iss $3 / \operatorname{art} 23 /$

Wilby, R. L., and S. Dessai. 2010. Robust adaptation to climate change. Weather 65(7)180-85.

Wolf, J. 2011. Climate change adaptation as a social process. Pages 21-32 in J. D. Ford and L. Berrang-Ford, editors. Climate change adaptation in developed nations: from theory to practice. Springer, Dordrecht, Netherlands. http://dx.doi. org/10.1007/978-94-007-0567-8 2

Yohe, G., E. Malone, A. Brenkert, M. Schlesinger, H. Meij, X. Xing, and D. Lee. 2006. A synthetic assessment of the global distribution of vulnerability to climate change from the IPCC perspective that reflects exposure and adaptive capacity. : Center for International Earth Science Information Network (CIESIN), Columbia University, Palisades, New York, USA. http://sedac.ciesin.columbia.edu/mva/ccv/ 